\title{
The Diary of Michael Stewart as British Foreign Secretary, April-May 1968
}

\section{Edited and introduced by John W. Young, University of Nottingham.}

The Labour governments of 1964-70 are probably the best served of all post-war British administrations in terms of diaries being kept by ministers. ${ }^{1}$ In the mid-1970s a very detailed, three volume diary of the period was published by Richard Crossman, after a lengthy court battle over the legality of such revelations, and this was followed in 1984 by a substantial single volume of diaries from Barbara Castle. Both were members of Harold Wilson's Cabinet throughout the period. Then Tony Benn, a Cabinet member from 1966 to 1970, published two volumes of diaries on these years in the late 1980 s. $^{2}$ However, these were all on the left-wing of the party giving, perhaps, a skewed view of the debates at the centre of government. To achieve a balanced perspective more diary evidence from the centre and right of the Cabinet would be welcome. At least one right-wing minister, Denis Healey, kept a diary quite regularly and this has been used to help write both a memoir and a biography. But the diary itself remains unpublished and the entries in it evidently tend to be short and cryptic. ${ }^{3}$ Patrick Gordon Walker, an intermittent Cabinet member and a right-winger, kept a diary only fitfully during the government. ${ }^{4}$ But the diary of Michael Stewart, a party moderate has now been opened to researchers at Churchill College Archive Centre in Cambridge. This too is restricted in its time frame but it casts fresh light on a short, significant period in the Spring of 1968 when the government seemed on the brink of collapse and Stewart was faced with several difficult challenges as Foreign Secretary. While, in his memoirs, Stewart included quite a long chapter on his second 
term as Foreign Secretary, this was dull in style, bland in its analysis and said little beyond what was already publicly known. ${ }^{5}$ The diaries are rather more revealing.

Michael Stewart, one time President of the Oxford Union, was MP for Fulham from 1945 to 1979. A teacher by profession, he had first entered the Cabinet as Secretary of State for Education after the October 1964 election, which Labour only narrowly won. But he was moved to the Foreign Office in January 1965 to succeed Patrick Gordon Walker, after the latter failed to win election to parliament in a byelection. There were stronger figures with ambitions for the post, including Richard Crossman and Denis Healey, but Stewart had some experience in foreign affairs. He had served in the Middle East during the Second World War, was Under-Secretary of War under Clement Attlee in the late 1940s and had visited the USSR in 1963 with Wilson. In August 1966 Stewart was moved to head the Department of Economic Affairs, largely so that Labour's deputy leader, George Brown, could obtain the coveted post of Foreign Secretary. Harold Wilson had secured a much larger majority in the March 1966 election but, within months, economic uncertainty had thrown the government into turmoil. In July there had been a major currency crisis, forcing a round of expenditure cuts and raising the danger that Brown would resign. Another crisis, in November 1967, forced a devaluation of the Pound, weakening Wilson's position and raising the spectre that Labour would be decimated in the polls next time around. But the Prime Minister took the risk of accepting one of Brown's many offers of resignation on 15 March 1968, at which point Stewart returned to his old post. He did so when the government's fortunes were at their nadir, with the devaluation still fresh in everyone's mind and speculation that the government might collapse. He also faced a plethora of difficult challenges: the devaluation had been followed, in January, by the acceleration of Britain's withdrawal from its military bases in Southeast Asia 
and the Persian Gulf, a decision that upset many allies; just before the devaluation, Britain's second attempt to enter the European Economic Community (EEC) had been vetoed by French President Charles de Gaulle and it was not clear what the way forward was for Britain in Europe; and the Middle East was still unstable following the Six Day War of June 1967. Nonetheless, what seems to have inspired Stewart to start his diary-keeping once more, as of 1 April, was not any crisis affecting Britain directly but events surrounding the Vietnam war: following the communists' Tet offensive, American President Lyndon Johnson had, on 31 March, pulled out of that year's Presidential election, restricted US bombing of North Vietnam and offered peace talks.

These were not easy circumstances to return to the centre of decision-making on British external policy and the Chancellor of the Exchequer, Roy Jenkins, criticised the appointment as 'likely to perpetuate both the greyness and the stubborn traditionalism of the government. ${ }^{6}$ Comments on Stewart's greyness are legion. Thus one junior diplomat described him as 'rather dull but competent'; Henry Kissinger found him 'a decent, solid man, not brilliant or far-sighted'; while the Defence Secretary, Healey, found he had 'intellectual and moral integrity, but perhaps lacked the drive and imagination the job needed. ${ }^{, 7}$ Left-wingers, like Castle castigated Stewart for a lack of radicalism, not least because of his support for the Americans in the Vietnam war. ${ }^{8} \mathrm{He}$ was a convinced socialist but in a calm, reflective way and his shyness, linked to a pedantic streak, meant that he inspired little affection. Yet, Stewart was not lacking in positive attributes. Hesitant in private conversation he may have been, but on a public platform he was able, quick-thinking and tough, taking on critical backbenchers in the Commons and anti-Vietnam protesters in the Universities. He was hard-working, honest and even held the 'high-minded doctrine', unusual for a 
politician, that 'questions should be welcomed... with the intention, not of evasion, but of imparting information.' ${ }^{9}$ Stewart's reputation for coldness is offset by the case of Jack Ashley, who was struck by deafness while working as his Parliamentary Private Secretary but found his boss very sensitive and understanding. One of his Private Secretaries, Nicholas Henderson, devoted a chapter of his memoirs to Stewart Foreign Secretary, praising him for his humour, self-confidence and calmness under pressure. To another Private Secretary, Donald Maitland, Stewart was 'very businesslike... dedicated, most conscientious... a very patient, considerate man. ${ }^{10}$ In contrast to George Brown, Stewart was also loyal to Wilson which, in the circumstances of March 1968, was just what the Prime Minister needed.

Stewart kept diaries for long periods during his life, for much of the period 1959-64, for example, when he was Shadow spokesman on Housing and Local Government, and again in the years $1970-89 .{ }^{11}$ But, while in office time pressures evidently prevented his keeping such a record with the result that a diary only survives for about seven weeks in April-May 1968 (running out when a visit to Moscow was imminent) and for three days in 1969 (when like many other would-be diarists, he was unable to keep up his journal much beyond the New Year). Even for the periods that are covered, Stewart's entries are generally shorter than those of Richard Crossman or Barbara Castle. But they compare similarly to Benn and often cast light on a different range of problems to the other three, who were mainly concerned with domestic political events. The style of the diaries, like Stewart himself, is plain and direct. But he is much more revealing than in his memoirs about, for example, personal rivalries (with some irritation about Healey's attitude towards European co-operation), his view of Foreign Office colleagues (both ministers and officials) and divisions in the Cabinet. Despite his reputation as Wilson loyalist and a 
pro-American, he is critical of the Prime Minister's attempt to create a kind of 'inner cabinet' ( 3 April) and of the US reluctance to begin Vietnam peace talks in Warsaw (15 April). He is even revealing about certain questions relating to security and intelligence matters, including talks with the Home Office on restricting entry for certain parties into Britain (11 April) and a rather comical episode about a would-be, unnamed secret agent (8 May). A large range of overseas issues are touched upon, from Vietnam, East-West relations, the EEC and the Rhodesia problem, to the future of the Falklands and Gibraltar, the border dispute between British Honduras and Guatemala, policy towards the military regime in Greece, and attempts to reach a Middle East peace. But there are also comments on domestic politics, including the April reshuffle, Enoch Powell's attack on immigration and the ill-fated attempt to curb trades union power through Barbara Castle's 'In Place of Strife' project.

The handwritten diary for April-May 1968 is to be found in file STWT 8/1/5 at Churchill College Archive Centre, Cambridge, and that for January 1969 is in file $8 / 1 / 6$. Together they total about 14,000 words but have been shortened below to about 10,000. Stewart's own spellings, abbreviations and paragraphing have been followed as far as possible, even at the cost of some irregularities; but ampersands and 'plus' marks have been spelt out as 'and'; whilst a few obvious spelling mistakes have been corrected. Short omissions are represented by three stops (...) but there has been an attempt to minimise these, in preference for the reproduction of long sections of text. Omissions include many short meetings with little or no information on what transpired, personal non-political issues (including most weekends spent at Dorney in Surrey), notes of media opinion and a certain amount of repetition (notably his concern over student unrest and criticism of the Greek military regime). Long omissions include an appeal from the Caribbean against a particular death penalty 
being carried out (2 April) and Stewart's attendance at the annual National Union of Teachers conference (13 April). Round brackets are used for Stewart's own bracketed sections; square brackets are used for the editor's additions.

\section{The Diary}

1968

\section{$\underline{\text { Monday April } 1^{\text {st }}}$}

News of L. B. J.'s decision not to stand again, and of his Vietnam offer, which Harold [Wilson] and I had discussed at Chequers yesterday. ${ }^{12}$ No. 10 issue the statement of welcome we had planned. Morning spent in planning $\mathrm{H}$ [ouse] of C[ommons] statement, approaches to USSR, and answer to P[arliamentary] Q[uestion]s.

These answers go down well in the House - the Falkland anxieties are, I think, finally laid. ${ }^{13}$ Goronwy [Roberts] ${ }^{14}$ does not manage very well - partly because he is unwell. Statement on Vietnam well received, tho' some of our 'Left' are already arguing (a) that this shows Britain should have dissociated earlier - I reject this, saying that if we had our position as co-chairman wd. be dead, and that USA has now fallen into line with our view, expressed nearly two years ago, about unwisdom of bombing $\operatorname{cities}^{15}$ (b) that U.S. shd. give up all bombing - I reply that she has made substantial move and it is now Hanoi's turn.

See Soviet Ambassador; he gives stock re-statement of Hanoi's position, but there is nothing much to be concluded from this. (I am not in fact hopeful that US move will bring peace - at least not now; but over last 3 years US has moved a good 
deal and Hanoi a little, so in long term this initiative not wasted. For Hanoi or anyone to give a flat 'No' would place a terrible responsibility on them. I make these points on a Panorama program in the evening.)

\section{$\underline{\text { Tuesday April } 2^{\text {nd }}}$}

At Cabinet I report how events have moved on Vietnam. Some voices, notably Dick $\operatorname{Marsh}^{16}$, urge re-consideration of whole V[ietnam] policy and dissociation from USA. I point out this wd. be absurd when they have just made a peace move: and that we must consider more fully when we know American reactions and Hanoi's reply. I agree (Barbara [Castle] and Tony Benn pressing this ${ }^{17}$ ) that if Hanoi says no, we do not at once burst into condemnation of Hanoi and give unlimited support to U.S.

Evening, Mary ${ }^{18}$ and I go to dinner at Chilean Ambassador's.... Am called away to No. 10 to discuss impending Cabinet re-shuffle with Harold. Roy [Jenkins] ${ }^{19}$ has objected - so strongly to Barbara going to D[epartment of] E[conomic] $\mathrm{A}$ [ffairs] that Harold gives up this idea - proposes to put her at Labour, giving that Ministry charge of prices and incomes and productivity - then to offer DEA to Denis $[\text { Healey }]^{20}$, though (from what Denis has earlier said to me) I do not think he will accept. Harold also plans to create a steering cttee of the Cabinet of about 10 of us this to meet weekly, while Cabinet meets every 3 or 4 weeks. I feel he has not given sufficient thought to this and say so.

\section{$\underline{\text { Wednesday April } 3^{\text {rd }}}$}


Morning, P[arliamentary] L[abour] P[arty] about Vietnam; I speak at beginning and end; about 50-60 people. Restrained atmosphere; fair amount of support - usual demands for dissociation and demand for total cessation of bombing, which I resist and am very glad I did when Hanoi's surprising - if very limited reply - is published in the afternoon.

Afternoon meet Steering Cttee of F[oreign] A[ffairs] Group - which owing to the packing of a meeting some time ago is composed almost entirely of fellowtravellers. We have, however, reasonably satisfactory discussion. Then...Vietnamese Ambassador, to who I strongly advise that his Govt. should not reject or pour scorn on Hanoi's message.

We draft brief message of welcome of Hanoi's position, and I say a piece to this effect to I[ndependent] T[elevision] $\mathrm{N}[\mathrm{ews}]$ outside the office. It looks as if the Co-Chairmen retire to the wings for a bit, but this need not matter

\section{Thursday April $4^{\text {th }}$}

News that Americans will meet N. Vietnamese - place not yet decided, but Moscow is rumoured. Things will probably soon assume a more difficult guise.

Morning, difficult meeting of the approach to Europe Cttee, to consider when and how we reveal to Europe our decision not to proceed with certain space projects. ${ }^{21} \mathrm{~F}$ [oreign] $\mathrm{O}[\mathrm{ffice}]$ proposals on this have no friends, but I sense that method of disclosure will be in F.O. hands, with messages from me to the Foreign Ministers.

Afternoon, clear off a good deal of constituency work; then receive six Ambassadors - including Libya and Lebanon who want to talk about Israel. I suggest 
to them that a way forward might be for Israel to state she would carry out UN res[olutio]n about withdrawal, and Arabs would then meet her to discuss how withdrawal to be carried out (cf. Hanoi insisting on uncondit[ional] withdrawal, but offering to discuss how it is to be carried out). ${ }^{22}$ Libyan interested, Lebanese cautious. Talk with Y[ugo]slav ambassador about European security - put it to him that if Germans could make satisfactory statement about Oder-Neisse, Russians ought to move to united Germany - he does not like the idea of united Germany, but sees my point about the danger of keeping Germany with a justifiable grievance, while at the same time both East and West re-arm her. ${ }^{23}$

\section{Friday April $5^{\text {th }}$.}

Morning, PM's weekly meeting - where we discuss, in addition to routine matters, the coming reshuffle. It appears - and this is made clear when the announcement is made - that Barbara's posn. as minister of Labour and $1^{\text {st }} \mathrm{Sec}[\text { retary }]^{24}$ and Prices, Inc[omes], Prod[uctivity] is very powerful and that therefore Harold has really got his way despite Roy's objections.

\section{Monday April $8^{\text {th }}$}

Two [Labour] MP's come to see me at the F.O. 1) Jimmy Johnson, about British representation in, aid to Somalia. I say that a Consulate General at Hargeisa is not on, but we may be able to establish British Council activity there, which wd. be more appropriate. On aid he must talk to Reg Prentice ${ }^{25}$, but I do not think we can do very 
much. 2) Tam Dalyell, with two businessmen concerned with cleaning the Suez Canal. ${ }^{26}$ They bring useful report suggesting that the difficulties about clearing the south end of the canal are considerable. This, if correct - which it probably is - and if we can convince the Israelis of it - which is problematic - might remove Israeli objections to clearing the north end and letting the ships out that way. Israeli fear is that if the north were cleared, south could then easily be cleared, and whole canal would be physically open before there was any assurance their ships could go through; then they would either have to acquiesce in continued discrimination against them, or strike. ([Abba] $\mathrm{Eban}^{27}$, indeed, had previously put to me the proposition that a blocked canal might be less expensive for the world than another M[iddle] E[ast] war. Our immediate intent is, for economic reasons, to get the canal cleared; Israel's is to avoid permitting the discrimination to be revived.) We agree that this report should be sent to the U.N. Secretariat, and that they should... approach the Israeli Govt. insurance broker. The whole thing more useful than Tam Dalyell's activities usually are.

Then see six Ambassadors, including the Liberian, who remarks, appositely, of the death Martin Luther King "Our religion has always said, no remission of sins without shedding of blood". 28

(“And Kings shall die for the people, in many places and times.")

After lunch meet Stan Henig, Eric Heffer and another Labour M.P. about approach to Europe. I reject "association" with EEC and on the whole they agree; they feel we should make some approach to France as well as the Five, but are not forthcoming with suggestions how this could best be done. However, what they say will be helpful when we come to consider the kind of initiatives we should make in May. 
Various comments in the House about the Govt. changes. Chris Mayhew ${ }^{29}$ remarks - truly - that there are still too many able and loyal members still on the backbenches, while there are incompetent junior ministers - they instance Gwyneth Dunwoody $^{30}$ and - to my regret - Goronwy Roberts (who never does himself justice in the House.) Jim [Callaghan] ${ }^{31}$ naturally annoyed that Harold had said nothing to him about putting Children's Dept. of H.O. into the proposed Social Services Ministry... However, in general, comment is favourable, as it is in the Press.

Confusion in the House about business, which is vexing to Fred Peart ${ }^{32}$ on his first day as Leader - and some of our people - [Willie] Hamilton, Leo Abse - show him no shadow of goodwill. This is the great evil of the PLP in this Parliament.

A great deal of heavy reading to do before I go to bed at 2 a.m.

\section{Tuesday April $9^{\text {th }}$}

$\mathrm{C}$ [entral] O[ffice of] I[nformation] photographers come to... take photos of Mary and me, for publicity and passport purposes. Then to Cabinet, where I report on Security Council (Rhodesia), Vietnam, and E[uropean] E[conomic] C[ommunity] - no special comments on any of these. Harold makes some comments on Govt. changes and assures Jim that press story of $\mathrm{H}$ [ome] O[ffice] Children's Dept. being absorbed in Dick Crossman's new job was NOT given to them by No. $10 .{ }^{33}$ If such a development occurs (and personally I think it will) it will be later and after discussion. We then discuss and approve H.O. White Paper on children in trouble.

Afternoon, discuss with Bill Rodgers and officials the line Bill is to take on Greece in Adj[ournmen]t debate on Thursday. ${ }^{34}$ Decide that, 1) without accepting torture of prison charges as proved, he is to say Greece has a case to answer 2) he 
should deplore disappearance of democracy in Greece 3) explain why we have not joined Scandinavian action on Human Rights, but make our own representations.

Harold tells me George Brown ${ }^{35}$ came to see him recently and told him, inter alia, that recently three leading Cabinet Ministers talked to him (George, before his resignation) about getting rid of Harold, and he told them they had not the support of either the PLP, the party in the country, or the country. George alleges he had the conversation tape-recorded - the three being unaware of this! (It seems to me that someone capable of doing this, or claiming to have done it, is equally capable of inventing the whole thing).

\section{$\underline{\text { Wednesday April } 10^{\text {th }}}$}

I see Sir Pat Reilly ${ }^{36}$, who confirms my view of de Gaulle's complete intransigence about our entry to the Market, but thinks this may well be possible after de G. has gone, whenever that may be. ${ }^{37}$ Then to Ministerial meeting at no. 10 . where we deal with some very heavy stuff about my approaching talk with [Joseph] Luns ${ }^{38}$ on gas centrifuges. Denis dislikes idea of my having these talks - he opposes anything that smacks of approach to Europe or helping the Benelux proposals - using arguments about danger of estranging U.S.A. I have to concede that we will tell Americans tomorrow, instead of Monday (the Luns talks are on Tuesday) - my talk with Luns to be conditioned by the U.S. reactions.

Lunch with... journalists... Return for difficult discussion with Denis about European defence co-operation - he is again being obstructive through wish to obstruct approach to Europe. I tell my people afterwards we must now work on 
assumption that Denis will take this line on any matter, and we must be prepared to meet it.

Then see Six Ambassadors; impress on Greek gt. interest in this country in internal affairs there, and our desire to see democracy restored. He assumes that the Colonels are men of honour and will carry out this pledge to provide a constitution. Colonels, he says, claim they are honest men, unlike politicians; I say I distrust these blanket attacks on politicians - if politicians are swept away what is left but armed force?

Short talk with Harold about tomorrow's Cabinet item on breaking the news to the Europeans of our policy on space; Harold proposes to try to get Cabinet agt. to the way of doing this which I proposed at EUR(M) Cttee [Ministerial Committee on Europe], but which Cttee rejected - that is, to get European agt. to call a conference on tech. co-op. as a whole, so that we have something positive as well as negative to say - the others want to break it to them without delay.

Drinks at No10. for Bill Rodgers group of Labour F[oreign] A[ffairs] M.P.'s. I am worried that I did not get on the right wave length with them... We learn depressing news that tomorrow's NOP Poll will show Tory lead of $22.5 \%$. It begins to look very likely that we shall (1) loose heavily including Hammersmith - in the Boro' elections. (2) loose the General Election, including Fulham. ${ }^{39}$

"Heart must be stouter, spirit must be keener

Will must be stronger as the peril grows great."

Dine with the Gore-Booths, and their son - very pleasant with a minimum of 'shop' ${ }^{40}$ I talk to Paul about Denis's attitude to our European policy.

Thursday April $11^{\text {th }}$ 
SEP [Steering Committee on Strategic Economic Policy] meeting with depressing news about trade figures and unemployment - as to the latter, although the actual figures go down, the trend is disquietingly up. Only bright spots are that productivity per man appears to be rising, and that, comparatively, the employment situation in the regions is better.

Cabinet: Harold and I loose on the question of approach to Europe, only George Thomson ${ }^{41}$ supporting us. We then approve a good England and Wales White Paper on repair of older houses; this is not to involve increased public expenditure as it is a switch from new building to repairs. The Scottish counterpart is held up as Willie Ross ${ }^{42}$ maintains that he cannot reduce building of new houses in Scotland, and the repairs must be additional expenditure. To this Roy rightly objects, pointing out that we have set our faces against patchwork bits of extra social service expenditure. OPD [Overseas Policy and Defence Committee]: decide that we should tell [Kenneth] Kaunda ${ }^{43}$ who has been clamouring, in letters to Harold, for extra aid to Zambia to help her over difficulties caused by sanctions, that if he likes to come to London he will be welcome, but we can hold out no hope of extra aid.

At office, decide on minute to Jim Callaghan against admitting the North Vietnamese propagandists for C[ampaign for] N[uclear] D[isarmament]'s rally; we shall do this partly by delaying tactics which will bring home to N.V. the difficulties caused by the delays they always impose on traffic between our Consulate-General in Hanoi and London - but in the main because if we give impression of weakening at this moment this may encourage Hanoi in intransigence.

I decide on message to Pat Dean ${ }^{44}$ in Washington, to the effect that we believe U.S. will be unwise to cause talks to break down because agreement is not reached on 
the place. So far, Hanoi has proposed, but dropped Phnom Penh, and proposed Warsaw; U.S. has made counter suggestions of Delhi, Rangoon, Djakarta.

\section{$\underline{\text { Saturday April 13th }}$}

Donald Murray ${ }^{45}$ rings from the F.O. Pat Dean transmitted my message... The Americans still inclined to be difficult about the place, and have sent a message to me, via their Embassy, asking if we will support them in resisting Warsaw. When Donald Murray tells me this, I say we cannot do it - and that if Parliament were sitting I should be under pressure (which I should resist) to criticise them for not at once accepting Warsaw. Agree with Donald a reply - since the Americans specifically ask for HMG's view - saying that they would be ill-advised to go on making difficulties, and that if they appear as the generous ones now, they can make good use of this later on some more vital point - also that LBJ's repeated declaration of willingness to meet "anywhere" will be repeatedly quoted. Apparently, Americans dislike Warsaw really because they hope the first talks will widen into something more, for which Warsaw would be difficult. Meanwhile, there are suggestions that it will be Paris, and this might well be correct.

\section{$\underline{\text { Monday, April } 15^{\text {th }}}$}

Morning, do the walk in Egypt Woods, weather very good, though still rather cold.

On our return, message to ring the office. This is about Press reports of what we have said to Americans (see Sat. April 13 ${ }^{\text {th }}$ ) I had seen these, and judged it might be leak from American sources. Donald Murray tells that in fact someone in our News Dept. 
inadvertently let it out in an off-the-record briefing of diplomatic correspondents, all of whom seemed to be critical of Americans. I say that this, tho' inadvertent was fortunate - good, as far as opinion at home and our general stance is concerned, that it should be known we had spoken as we have to the Americans, and good, vis-à-vis Americans, that the fact should become public in this oblique way rather than by open statement from us. Murray agrees. He says Paul [Gore-Booth] has suggested I send similar message to Hanoi, so that I can say, if pressed, that we have equally approached both sides. This is all right, though the presentational use of this is really only of use towards the Americans. I therefore agree to send message (It ought of course to be [Andrei] Gromyko ${ }^{46}$ who approaches Hanoi on these lines and he may, of course, have done so.)

\section{Tuesday, April $16^{\text {th }}$}

To London, for talks with Jo Luns.

(1) Acarius ${ }^{47}$ - it looks as if we were just in time, as the Dutch are on the point of talking at official level with the Germans. We agree that Solly Zuckerman shall talk to de Bloch ${ }^{48}$, and Luns takes back to his Govt. the news that we went to talk with them - a development which he had expected and will recommend to his Govt. (2) Space - he is, as I expected taken aback by our decision, but far more concerned with the political effect and the use the French may make of our decision, then with the merits or demerits of the decision itself.

(3) Europe. He gives entertaining account of various episodes at the meeting of the EEC Ministerial Council; he has evidently been trying, with some success, to put vigour into the Germans. He wants to see the "albatross" of their veto firmly fastened 
round the French neck. Our policy, therefore, and that of the Five ${ }^{49}$, should be to do as many things outside the context of the Six as possible (this the opposite of the policy [Walter] Hallstein ${ }^{50}$ described to me, some three years ago - he wanted the Six to cooperate, to the exclusion of others, in as many fields as possible.) He commends our idea of an initiative on Benelux lines in May, saying we need not worry about FrancoGerman proposals, since France has made them negligible. He thinks [Amintore] Fanfani ${ }^{51}$ might be induced to take initiative in calling conference of the Six plus U.K. - tho' realising that France would not attend. He will try to persuade Fanfani to come in person to W[estern] E[uropean] $\mathrm{U}[\text { nion }]^{52}$ meeting in Paris - this, after I had said I would be inclined to go but for the fact that I should be, probably, the only Foreign Minister there.

He is unhappy about Belgium, seeing no clear pattern of a viable Govt. emerging, and regarding the break-up Belgium and the incorporation of its parts into France and Holland as impossible, if only for the reason that Holland would not want the structure of her state complicated by federalism, nor wish to see a strengthening of the Catholic Party. He describes [Willy] Brandt ${ }^{53}$ as going steadily downhill. (4) KLM facilities in Hong Kong. This subject he raises with me in entirely private conversation at outset of talks. He had learnt, via our embassy in The Hague, that I was going to say that the study of this matter (B[oard] of $\mathrm{T}[$ rade] are being difficult) which George Brown had described to him, was continuing and that I could not give a commitment. This was indeed what I had planned to say and I believed it was consistent with what George had told him 2 months ago. Jo, however, says that George assured him in private that the matter would be settled, in the way the Dutch wanted, within 2 months from their conversation. George had no authority to say this, and - as I later learn from Donald Maitland ${ }^{54}$ - told no one in the office that he had 
said it, but gave them to understand that he had been non-committal. I have to be frank with Luns and say that the only undertaking I can give him is that I want to get the matter settled to the Dutch's satisfaction, but cannot pledge.

(5) Vietnam. I give short account of our position and activities to date, with which he is in clear agreement. I add that, in the complexities of all this, and in face of U.S. errors of judgement etc., there is danger of losing sight of the great issue of human liberty which divides us from the Communists and for the sake of which we must prevent estrangement between W. Europe and the U.S. To this also Luns agrees.

\section{Wednesday April $17^{\text {th }}$}

An idle day at Dorney...The 10 p.m. television news presents a depressing picture student violence, Greek dictatorship etc. The great difficulty of the world is the moral deficiencies of what should be the free world - Greece, Portugal - Germany distracted, France selfish, ourselves aimless, U.S.A. in torment.

\section{Thursday April $18^{\text {th }}$}

We return from Dorney and I spend the day on constituency correspondence, and a large mass of F.O. papers - in particular CENTO [Central Treaty Organisation], to which few Foreign Ministers are coming, this is on the whole good as we want to play the organisation down rather than $\mathrm{up}^{55}$ - and the Falklands - we intend to resume talks with Argentina, but outlook is uncertain. P[ermanent] U[nder-]S[ecretary] thinks we had better begin thinking of re-settlement, but I do not believe this to be right. 
Friday April $19^{\text {th }}$

Morning at office; briefing on CENTO; it now appears that Turkish and Iranian Foreign Ministers are coming. The real purpose of the conference is to keep the regional members - Turkey, Iran, Pakistan, - content and to promote a limited amount of economic progress. One would not try to create CENTO if it did not exist, but, as it is, it has some use - it has probably been some restraint on the Shah in his excitement about the Gulf. ${ }^{56}$

Then a discussion on the question whether we can assure a South Africa firm thinking of giving a contract to a British firm, an assurance that HMG would not contemplate allowing possible future sanctions on non-arms trade with S. Africa to interfere with existing contracts. I decide that we should - Fred Mulley and Denis Allen ${ }^{57}$ agreeing, and several of our U.N. people disagreeing. The argument against is that this commits us to a line that would be held to derogate from the UN's authority, and might damage our standing with African members of UN. Argument the other way is that we shall not, in fact, agree to sanctions against non-arms trade with S. Africa, still less to their interfering with existing contracts - so why lose trade by declining to say so. I hope and believe we took the right the decision. ${ }^{58}$

Afternoon, talk with PUS about the merger. ${ }^{59}$ He considers a high-powered group should be studying it, and that this should include his successor - so we should decide who is to be his successor, and various consequent appointments. I agree to this; am myself strongly in favour of Denis Greenhill as his successor. ${ }^{60}$ He envisages appreciable economics in manpower from the merger. Meanwhile Malcolm Shepherd $^{61}$ from C[ommon]wealth Office puts in a plea for special treatment, in the merged office, of Dependent Territories, opposing the idea of arranging the Depts 
geographically; he is quite wrong about this. I talked to Fred Mulley about Ministerial duties; Alun Chalfont ${ }^{62}$ wants more to do, but, in the light of his views, I do not propose to give him NATO.

An hour with the French Ambassador, as a prelude to my meeting with [Maurice] Couve de Murville ${ }^{63}$ next week. We discussed Common Market, Vietnam, Middle East, but to no great purpose. French clearly want us to get entangled in belated talks with them, which they can represent to the Five as our double crossing the Five.

Read two interesting letters 1) From Frank Roberts to PUS, describing how annoyed Germans were not getting Con O'Neill; in particular, Brandt and other SDP'ers annoyed that George thinks Con too intellectual for them. ${ }^{64}$ 2) From [Ambassador] Michael Hadow in Israel describing what [Yehuda] Avner ${ }^{65}$ (who was here with Eban on his recent visit) had said about my talks with Eban: he was most laudatory, saying that although what I said was tough in substance, I won their sympathy, and Eban will argue on the lines I wanted in the Israeli Cabinet - but whether he will be successful is another matter.

$\underline{\text { Sat }- \text { Sun April } 20^{\text {th }}-21 \text { st }}$

At Dorney, on Sat. we visit the Stanley Spencer exhibition at Cookham in the morning. For the rest of the day, and on Sunday morning, I have a great deal of work to do. Telephone calls from office about British Honduras; the Mediator's report is available and is more favourable to Brit. Hond., and less to Guatemala than might have been expected. [Emilio] Arenales , Guat[emalan] Foreign Minister, alarmed about this, wants to me and wants us to hold up publication. ${ }^{66}$ Decide that he can meet 
Fred Mulley - who is now on his way to New York - and that we can delay publication perhaps till Thursday but scarcely beyond that.

\section{Monday April 22 $2^{\text {nd }}$}

Morning, sign Outer Space Treaty with David Bruce and [Mikhail] Smirnovsky. ${ }^{67}$ Then talk with Nick Katzenbach, Rusk's deputy. ${ }^{68}$ I urge the importance of not wrecking Vietnam peace talks by haggling over site: he says their Kremlinologists advise that if they let themselves be pushed around on this, there will be no end to it; also, that if they accept Warsaw for first talks it will be difficult to move, for extended talks, to a place where their allies as well as themselves will have proper facilities. We also discussed Rhodesia and Middle East.

Then to Turkish Embassy for talks with their Foreign Minister, [Ihsan Sabri] Caglayangil. He agrees on importance of restraining the Shah in his zeal against panArabism in the Gulf. On Cyprus, says Makarios is tricky, and that Turks will not agree to talks in Cyprus. I suggest British Sovereign Base Areas, but he is not enthusiastic. ${ }^{69}$ On Middle East he leans more to Arab line than we do. We then lunch, most of the chief CENTO people being present. [Abbas] Aram, Iranian Ambassador says that if we want Tehran for next year's CENTO we should get off message to our Amb. there at once, so that Shah can consider it.

Further conversation with Nick K. and Denis Healey after lunch. K. says he does not think American policy on Vietnam will change much, whoever becomes President - even if it were McCarthy ${ }^{70}$, which he thinks unlikely.

Return to office - hurried constituency work... Then discuss how to handle [Ardeshir] Zahedi (Iranian F[oreign] M[inister]) who arrives tomorrow. Then some 
special security discussions with Denis Greenhill (bag-rifling and the Dutch, bribery of [Kurt] Thadden of the NDP ${ }^{71}$, 'phone interceptions). Discuss with PUS, and agree to appointment of Trefor Evans ${ }^{72}$ as our Amb. in Baghdad - he is not first class, but Iraqis want Amb. exchanged quickly after resumption of relations, and we do not want to miss this opportunity.

\section{$\underline{\text { Tuesday April } 23^{\text {rd }}}$}

Morning, opening of CENTO. F.O. has prepared two skilful speeches, for Harold and myself, which without sounding empty say very little. We deliver them. Then get quickly through Sec-Gen's report and adjourn at 11.00.

Lunch at Persian Embassy which is very enjoyable. Zahedi has arrived and in the afternoon I talk with him. He is quite hopeless and evidently expects us to incur odium in Arab world by giving to Iran the disputed islands (I point out, repeatedly, that they are not ours to give and that we do not accept Iranian claims to them.) - and consequently will not consider any other way of dealing with problem - rejects my suggestion of reaching understanding with Saudi Arabia. Apropos of the frustrated visit of the Shah to Saudi Arabia he tells long story one item of which is that he 'pulled the leg' of the Saudi Minister by saying 'I see Egypt's hand is still astray in your country.'

Dinner with Cento delegates at Windsor. Take opportunity to tell Nick K. of our message to Hanoi, longish talks with Duke of Edinburgh - this is a bit frustrating as he forms firm opinion on inadequate facts and seems incapable of understanding anything that is inconsistent with them. 
(Burke Trend ${ }^{73}$ brings me the PM's letter making me his No.1 deputy in grave emergency.)

\section{$\underline{\text { Wednesday April 24 }}$}

Morning, Cento continues competently but placidly, ending at 12.45. During morning, hear that [Alec] Douglas-Home ${ }^{74}$ is to put $\mathrm{P}$ [rivate] $\mathrm{N}$ [otice] Q[uestion] about the UK resolution we have just tabled. ${ }^{75}$ So, after Cento, to office where we discuss this. Question is asked and all goes well; I make these points 1) we do not rule out all consultation - see PM's statements March $14 \& 27$ - but the hangings and the new 'draft const[itutio]n.' show the vainness of D-H's hopes 2) our resoln. will require others to do what we are doing - so, on narrowest basis this is not damaging to our trade 3) Rhodesian exports down since UDI - sanctions serious, but it may be a long business - we have to show that there is no future for the illegal regime. 4) (For our own people) we recog. diffic[ulties] over S. Africa and Portugal but it is no good sponsoring or voting for resolutions which we cannot carry out. ${ }^{76}$

Then back to office to phone, trans-Atlantic, to Arenales, who wants us to delay publicn of Honduras Mediation Report. After some haggling I suggest that since he said he wanted a meeting, 'at any level, even for 24 hours' - that we send extracts to reinforce Fred Mulley who will talk with him Fri. or Sat. - but I can give no guarantee that he will get anything from the talks. He agrees, so I agree to delay publicn till Monday - but we must then publish report as it stands.

Thursday April $25^{\text {th }}$ 
Morning, first meeting of the newly established Parl[iamentar]y Committee of the Cabinet - tho' this is not yet formally constituted. Present - Harold, Roy, Gerald Gardiner ${ }^{77}$, Denis Healey. Dick Crossman, Fred Peart, Tony Crosland, ${ }^{78}$ Willy Ross and George Thomas ${ }^{79}$ - since Scotland and Wales must be represented - and myself. Jim Callaghan wd. have been with us, but is visiting Jersey. We run through Parlty business then consider Race question. Since Powell's violent speech there have been many expressions of support for him - notably from dockers, who stop work to march to the House in his support. ${ }^{80} \mathrm{We}$ decide that all Ministers must be provided with a brief so that we can make clear to the public (i) the extent to which immigr[atio]n is controlled. (ii) the factual reply to the legends about the laziness, criminality etc. of immigrants and how dependent we are on them for essential work. (iii) the nature of case for the Race Relations Bill. I draw attention to the fact that if we resolutely oppose Powellism we may get more allies than we think - polls show majority support for the Bill, especially among young people and those who stayed at school beyond 16 - both of these groups of growing influence. Powell's talk of black people ultimately having ' the whip hand' is not only factually nonsense but illustrates his general conception of human relations as conflict - cf. his attitude about incomes policy, that each man shd. fight for his own land. He believes, not merely in race hatred, but hatred. None the less he will command much support, as my post already begins to show.

Lunch at Danish Embassy for King and Queen of Denmark. Sit next to Queen, who is very good company - talk about paintings, gardens, race problems etc. in a way which would be impossible with our own Queen, or with Duke of Edinburgh.

Back to office to talk for half-an-hour with Herr [Heinz] Kuehn, President of North Rhine-Westphalia Land. Their student problems are like ours, complicated by 
the obstinacy of their professors in refusing reasonable student demands about the running of Universities. He is worried lest student unrest links with working-class unrest - e.g. miners concerned over loss of jobs.

Talk with G. Thompson and PUS about merger, and we agree on certain top apptments which must be put to P.M.

Then catch plane to Paris for W.E.U. Have briefing talk at British Embassy from which it appears that [Andre] Bettencourt - French Minister of State for Foreign Affairs - is being as awkward as the French usually are at WEU mtgs.

At and after dinner talk with Dutch and German representatives. Germans have put forward some vague ideas about 'trade arrangements' between U.K and EEC. We do not think - especially as French have knocked them about in Franco German discussions - that these are likely to be much use; but French have been telling Germans that we are not interested at all, in the hope of making Germans feel that we are not worth bothering abt. I make clear that if their ideas turn into proposals from the Six which are unmistakably linked with our entry, we wd. look at them with interest; but we are not interested in substitutes for entry. Germans accept. The Dutch also understand it, but they also (even more than we) think that these ideas will come to nothing. From our pt. of view, best result wd. be that French obstinacy shd. convince Germans that it is the French, not we, who really block progress. As inspired French press are already saying that these ideas cannot be linked with our entry, things may fall out the way we want.

Friday April $26^{\text {th }}$ 
Morning, WEU. I make statement about U.K. economy, E[uropean] F[ree] T[rade] $\mathrm{A}[\mathrm{rea}]^{81}$, and - above all - our (and others') entry into EEC. Make quite clear that we want full membership, and state the posn. about interim action that I defined last night. Statements from others welcome all this, accepting our view that 'trade arrangements' must be, as I put it, 'clearly and inextricably tied' to entry. French del[egate] says no objection in principle to enlarging Community, but Britain not yet ready to take on obligations. [Henri] De Koster of Holland chips in saying Britain had shown her determination to take severe measures to get her economy right, and by the time negns. were through it wd. be right, so negns. shd. start at once. Belgium, Germany, Italy, Lux[embourg] express strong support for this view. So we have achieved immediate objective of making UK posn. clear (despite change of For. Sec.) and keeping the Five enthusiastically with us.

Lunch at Quai d'Orsay with Couve de Murville as host. During and after lunch I talk with him (3.0-4.30.) I make our posn. on Europe quite clear; he, for his part, seems to be saying that when our economy is clearly right, negtns. cd. begin. We discussed Vietnam, M[iddle] E[ast], Rhodesia - not to much purpose except that it seems possible French might reconsider their abstentions on the Rhodesian issue.

Do short interview for French TV, speaking in French. Then press conf. for British journalists.

Altogether a successful day - office v. pleased, saying I 'won on pts.' with Couve.

Meanwhile opinion polls show 79\% for Powell - but still, majority for Race Reln Bill, so people are evidently not v. clear. Heath, to his credit, continues to resist Powell. Polls on voting intentions are now quite appalling now for us - some give Tories 20\% lead, some $28 \%$. 
Saturday April $27^{\text {th }}$

In morning, papers come from office concerning aid for South Yemen, where negotns. are being difficult. I approve a minute to Chancellor asking that we should offer about $£ 600,000$ more - they might accept, which wd. be worth it, and if they refuse, cannot very well blame us for breakdown. ${ }^{82}$

\section{$\underline{\text { Sunday April } 28^{\text {th }}}$}

All day conference of Cabinet and N[ational] E[xecutive] C[ommittee of the Labour Party] at No 10. It deals entirely with Home Affairs, save for brief reference to need in 1970/1 El[ectio]n Manifesto for something about international scene. Denis Healey, who takes every chance to talk foreign affairs, says only that posn is in such a state of flux that we cannot yet decide what to say. This is obviously true, and I say nothing.

Mornings discn. on the economy brings nothing new: T[rades] U[nion]ists repeat their objns. to statutory powers on prices and incomes. Barbara and Roy speak well - Barbara saying that just as she is made the scapegoat for motorists refusing to accept drinks, so she can be made scapegoat by T[rades] U[nion] C[ongress] for rejecting claims; in both cases the motorists and T.U. leaders will know in their hearts that she is right. Roy stresses absolute necessity of getting economy right.

Afternoon, v. good opening by Willy Simpson ${ }^{83}$ on social policy, and useful discussion follows, Dick Crossman winding up. Final session on policy for next Election opened by George Brown and wound up by P.M. - nothing very much 
emerges, but at the end of the day there is reasonable harmony between Cabinet and NEC.

Argt. in Sec. Council about Rhodesia is going heavily - Danes... are being difficult, as are also Latin Americans.

\section{Monday April 29}

Morning, at office we discuss (1) My statement on Br. Honduras/Guatemala. The mediator's report is more favourable to B. H. than had been expected - which is why Arenales was worried (see Wed. April $24^{\text {th }}$ ), as he and his colleagues had not prepared G. opinion for this. However, at his talks with F. Mulley he had agreed not to object to publication of the Report and not to fly off the handle about it - at once, at any rate. I make statement in the House in the afternoon and it goes well. (2) EastWest relations. I put the case that, to hold public opinion on NATO - which is now 20 years old - we must either devise something truly better, or demonstrate that this cannot yet be done. At any rate, NATO must appear as interested in détente. It is argued that much is being done on these lines, and I ask for paper on this.

(3) The Sachsenhausen case, about which the Select Cttee. of the Commons concerned with the 'Ombudsman' is very excited; they want to pillory one of our officials, [George] Littler, despite the fact that the Ombudsman did not mention him and if he had intended to, would have had to observe the procedure set out in the act. With great difficulty we persuade the Attorney General to put to the Cttee. the case for being restrained. Afterwards I enquire, privately, of PUS whether there was, in his view, any mal-administration. He thinks the matter was not handled to perfection 
(what is?) but that the O's remarks were not justified - in Paul's view, O. was anxious to get his office a better Press. ${ }^{84}$

Talk with Frank Roberts ${ }^{85}$, now back from Germany. He tends to agree with Herr Kuehn (April 25 ${ }^{\text {th }}$ ) about student disturbances and NDP - but, like me, is still apprehensive of resurgence of Nazism, partly because German desire for order may produce backlash against left-wing students. Nor does he rule out the possibility, in certain circumstances, of Germany swinging to Russian camp if thereby she could get East Germany.

\section{Tuesday April $30^{\text {th }}$}

George Thomson and I meet P.M. and get his consent to Denis Greenhill being designate PUS of the merged office. I learn that Arthur Bottomley's appointment as High Commer. in Kenya is inevitable. ${ }^{86}$ We discuss possible candidates for peerages Paul Gore-Booth, Morrice James ${ }^{87}$, Frank Roberts, of whom P.M. has not as high an opinion as I have.

Back to office and discuss aid to S. Yemen with Alec Douglas-Home and Charles Mott-Radclyffe ${ }^{88}$. They do not want any aid to be given. I point out we are giving v. little and it will be conditional on S. Yemen honouring its pension obligation to pensioners in their country. They do not apparently feel very strongly, but think that some of their Tory colleagues will.

See Jim Callaghan and get his agreement to 'phone-watching certain "students" - for a month. Discuss visas for N. Vietnamese propagandists and argue they should be refused in view of (1) Fact that NV journalists are here and can put NV 
view. (2) The people in question are dubiously sponsored and not interested in making peace (3) The present delicacy of the situation.

After lunch, constituency work, then PM's questions, then back to office to talk to diplomatic correspondents - usual subjects, goes well. Then see Sir G[eoffrey] Harrison, on leave from Moscow. He draws picture of fermenting E. Europe - USSR alarmed at this and clamping down on free discussion at home. We both think that, over a long time, they will get more liberal - and we, I think, more Socialist in the economic sense.

\section{$\underline{\text { Wednesday May } 1^{\text {st }}}$}

In the morning discussion with Denis Healey about increased contribution to NATO (very modest) now that we are withdrawing from the Far East. We agree on this, but discussion on European defence co-operation is more difficult. I want to pursue Benelux proposals, which includes discussion with the Five and the candidates for EEC membership, concerning defence; Denis, basically disliking EEC, tries to obstruct, but we make some progress.

Then see Argentine Ambassador and put to him our draft of Clause 4 of the proposed Memo. of Agreement on the Falklands; this lays down that before the transfer of sovty, U.K. must be satisfied that Islanders are satisfied: Argentine draft says we must be satisfied after consultation with the Islanders. Ambassador goes some way toward saying that altho', strictly speaking, the Agt. wd. be between two Sov. States - U.K. and Argentina, and therefore Islanders shd. not be given veto, in fact we all know what the posn. is. (ie. that Islanders must agree.) I also point out that if Argentina lifts the ban on movement of Islanders, some time must elapse before this 
produces effect - I therefore show him our proposed para. 6 , which enshrines this idea and suggests that if, 10 years after restrictions on movt. are removed, we still do not consider time ripe to transfer sovereignty, Govts. shd. consult. To my surprise he does not react violently to this...

See Prince Sultan of Saudi Arabia. For the most part we exchange platitudes. He agrees that S.A. and Shah shd. work together, wants us to help the Emirates, and dislikes S. Yemen. Then we get on to Israel. I agree with him about need for I. to say clearly that she accepts UN resolution... but point out (which he does not quite like) that I. wants recogn, end of the state war, free passage through Canal.

A very sad letter from Jack Ashley; he is now totally deaf. I must call in help (Harold etc.) about a job for him. ${ }^{89}$

Thursday May $2^{\text {nd }}$

Meeting of Parlty. Committee, followed by Cabinet. This has the unsatisfactory result of some of us having to discuss the same subjects twice. Among these are the party situation concerning Prices and Income Bill. The Govt's majority is now 72 and there is talk of 64 abstentions! - but in fact it will not be as serious as this. On the racial question, it is decided to try to get all-party discussion on the control of immigration, but to do this after Race Relation Bill is through, - we do not propose to make any substantial concessions on this. Even so there is a danger that such talks would mean that each Party wd. bid for popular favour by proposing a lower figure of total immigrants.

I reflect on Overseas Affairs, mentioning my intention NOT to attend Israeli $20^{\text {th }}$ anniversary reception since Israelis are ignoring Sec. Council resoln. on their 
arrogant victory parade in Jerusalem. Goronwy Roberts will go, and there is no objection to other Senior Minister (not F.O. or C'wealth Office) going - indeed, they may take opportunity to tell Israelis what we think.

Dick Crossman makes criticism of Paul Gore-Booth for his two day excursion to Switzerland to enact the Holmes-Moriarty episode. ${ }^{90}$ I rebuff this - it is fantastic, but Civil Servants have a right to use their leisure as they wish.

Friday May $3^{\text {rd }}$

See UAR Ambassador, who looks a defeated man. He professes UAR willingness to talk with [Gunnar] Jarring ${ }^{91}$ - and so, indirectly, with Israel - if Israel unequivocally accepts Sec. Council Resln. and declares readiness to implement it. I put this to Eban when I meet him in the afternoon, and urge again on him need to make a statement of this kind and to refrain from provocative acts such as the parade. He replies that Jarring has reported to them an attitude of almost total un-co-operation in Cairo; and that Israelis believe that, whatever statements they might make, Egyptians will not talk or work towards a full settlement. So, all told, we get no further.

Meeting of OPD at which we decide on complicated instructions to Lord Caradon about how far he may go in meeting Afro-Asian points on our Resolution; he is still having difficulty in keeping Danes and Latin Americans in line with us. We also reaffirm, despite plea from Eddie Shackleton, that we will not improve our offer of aid to South Yemen beyond $£ 1$ 3/4 million.

Lunch with American correspondents, which goes well - they question a good deal on Vietnam. News comes later in the afternoon that agreement has been reached 
on Paris as venue for talks. This is good news, despite the fact that it will further inflate de Gaulle.

$\underline{\text { Monday May } 6^{\text {th }}}$

Talk to P.U.S. about his Latin America tour - some points of his report need to be urged on British exporting firms. See King Hussein [of Jordan]. He is entirely reasonable, and reports that his P.M., returned from Cairo, records that Egyptians will talk - and reach a real settlement - if Israel will make the necessary statement. Send Eban a message on the strength of this.

Spaniards have closed Gibraltar frontier. ${ }^{92}$ Reply to PNQ... on this; we shall continue to help Gibraltar, but keep for the present (at least until George Thomson has met Gibraltar Ministers tomorrow) an open mind about retaliatory action. Replying to the supplementaries I imply that individuals thinking of holidays in Spain should think again. Some trouble from Tory back-benchers, but it is noticeable that their Front Bench are restrained.

$\underline{\text { Tuesday May } 7^{\text {th }}}$

Discuss, with P.M., Tony Benn and Alun Chalfont, our policy on technology-sciencespace-Europe. The meeting is useful in stopping growth of misunderstanding between Mintech [Ministry of Technology] and the F. O. We in fact argued that this whole matter should be thought of in terms of viable industrial activity, with caution towards prestige space projects. Problem is to present this effectively to Europe. I have to make point that all relations with foreigners are a F.O. concern. It is agreed to 
establish Cab. Cttee., under Alun's chairmanship. Tony gives account of the work so far done in Mintech in identifying things for the projected European Tech[nology] Centre to do.

Chair, at F.O. conference of E. European Ambassadors. Extremely interesting. While events in each country have a local colour, there is a connecting thread of intellectual unrest, partly connected with the perennial conflict of the generations. Moral of this is the importance of maintaining cultural and intellectual contacts.

Over lunch, discuss with George Thomson the line to be taken in the Gibraltar S[tanding] O[rder number] 9 debate - we agree that there must be firm affirmation of our position, but that we cannot yet talk of retaliation - I urge that stopping the Spanish workers should be examined. In the event, the Opposition take a moderate line, and George does very well indeed.

Talk to Roger Jackling, before his departure to Germany. Among several points we note the importance of quietly convincing the Germans that de Gaulle is not their friend.

$\underline{\text { Wednesday May } 8^{\text {th }}}$ (Mary's birthday)

Smirnovsky comes to see me with oral reply from Gromyko. Will I meet him in Moscow on May 12/13? This is not possible, but, after S. has gone, we decide on May 21-23, which he will probably accept. The reply also mentions understanding of Hanoi's reply to Johnson - I say I always try to understand, but this does not mean agreement. Also refers to Geneva Agrts., to which I reply that the U.S. has already accepted this basis. I describe how I see Co-Ch'man's function - we must not merely reflect our own side's position but aim to narrow the gap. We send message to Rusk 
who returns agreeing, if countries reply - they do not want announcement made too soon after beginning of talks in Paris on the $10^{\text {th }}$; it may be difficult to meet this point.

Lunch at No. 10 with King Hussein - nothing very new emerges from this.

See Spanish Ambassador and make emphatic protest [on closing of land access to Gibraltar]. He replies along expected lines - is somewhat unhappy - he has been wounded by comments about him in yesterday's debate. To illustrate unanimity of Spanish opinion he quotes statement of one of the exiles. I reply we cannot produce that kind of national unity because we have no exiles; but he need be in no doubt of opinion in this country.

Fred Mulley draws my attention to a security case - a man employed by a semi-governmental commercial body to trade beyond Iron Curtain. The F.O., through a confusion of names, had informed his employer that there was no objection to his being so employed; we now find he was previously engaged on special work beyond the Iron Curtain, tho' at a low level. Danger is that Russians may discover this and seize him, to use, together with Brooke, as material for an exchange offer with the Krogers; moreover, Blake knew him well and may tell the Russians about him. ${ }^{93}$ Further he is clearly a silly man (a) On his last visit to Moscow he promised a chambermaid to take her some chocolates and other contraband stuff (b) he claims to have a connection with the P.M., and suggested P.M. should speak about him to Smirnovsky, so as to safeguard his position! I say he must not go back over the Curtain - we shall have to admit our error to his employers.

Discuss (tho' not apropos of this) general nature of security precautions. Pay short visit to Great Britain-East Europe centre; then Mary and I go to Mansion House dinner in honour of EFTA delegates... 
During the afternoon, visit from [Valery] Giscard d'Estaing ${ }^{94}$, who makes two interesting comments 1) French veto in 1963 was due to our lack of resolution - at one time de Gaulle and Couve de Murville were convinced that they wd. not be able to keep us out 2) If there is any reshuffle of French cabinet, Couve will become P.M. - this is surprising, and I doubt whether it is correct. ${ }^{95}$

\section{$\underline{\text { Thursday May } 9^{\text {th }}}$}

Vote in municipal elections. Then to Lancaster House for EFTA; make speech on Eur. integn., outlining our position much as I had done in WEU. The ensuing discussion indicates the spectrum of views, for Denmark and Norway's agrt. with us, through the problem of the neutrals, to the anxieties of Portugal.

Friday May $10^{\text {th }}$

Cecil King, in 'Mirror' and 'Sun' comes out with an article demanding that Harold should go and PLP find another leader. ${ }^{96}$

Difficulties have arisen over EFTA communiques and I have to go back to Lancaster House to sort this out. The question is the statement of our attitude to proposals from the Six for trade agrts. etc. - has Britain got to have all the EFTA countries participating in any discussion? - clearly this would not work, as there might be proposals affecting only applicant countries. In the end, we sort it out.

Then talk with Portuguese Foreign Minister about Rhodesia. Contrary to the impression he gave to me in a short conversation yesterday, he is not helpful; agrees with us that we want to avoid disorder in Africa, but considers [Ian] Smith's refusal of 
majority rule is helpful to this end. I say this is short-sighted - if Smith persists, guerrilla fighting will grow. He complains of the Beira patrol. ${ }^{97}$

All this prevents me from attending last session of East European Ambassadors Conference; but I look in at the Cocktail Party which concludes it. Then to Fulham for surgery. Altogether, a heavy depressing day.

\section{Monday May $13^{\text {th }}$}

We have now got it fixed that I go to Moscow on May 22 $2^{\text {nd }}$, and announcement will be made tomorrow. Talk at office about Copenhagen visit. Then speak to P.M. about the paper I am putting forward urging an initiative on Europe; he is strongly in agreement, but we shall have difficulties.

Afternoon to Copenhagen, where we are cordially greeted. Dinner with Ambassador (Oliver Wright) and his wife.

\section{$\underline{\text { Tuesday May } 14^{\text {th }}}$}

Talks with Poul Hartling, Danish F[oreign] M[inister] and Nyloe Anderssen (Trade). First I give him advance news of my visit to Moscow, about which (in itself, and my telling him) he is very pleased. Then we discuss trade matters and make reasonable progress. Lunch at City Hall where Chairman of the Council presents me with cufflinks which he calls 'handcuffs'. Resume talks in the afternoon and cover the international scene - first for half-an-hour with P.M. then with Hartling. All this goes very well indeed: the Danes (now on the Security Council) will, I believe help us get a reasonable resolution. 


\section{Wednesday May $15^{\text {th }}$}

Short audience with King of Denmark who is most friendly, and repeatedly asks me to remember the Queen and himself to Mary. He and Hartling tell me about their seamen's strike and the special legisln. being put through to end it and provide for compulsory arbitration. Denmark has no general powers to do this, but ad hoc laws of this kind are occasionally passed.

Then Press Conference, followed by lunch, with the Danes as our guests at the Embassy. Afternoon, excursion to Elsinore, where is Kronborg castle, the scene of Hamlet. Return to reception of British and Danish businessmen, then home. It has been an exceptionally useful visit. The Danes give us their customary presents of cheese and Pat Hancock says no British Foreign Secretary has been given so much cheese before. Hartling also gives me two handsome candlesticks - which we shall be very glad of for the dining room.

News that Harold did extremely well at PLP meeting on Prices and Incomes. Only 42 vote the wrong way. Following my talk with Jack Ashley on Sunday and some tea-room talks, I had said to Harold on Monday (1) Stick it out (2) Give attention to the problem of communication between Ministers and back-benchers. Cecil King's campaign against him seems to be a flop, and the Party is rallying.

\section{Thursday May $16^{\text {th }}$}

Parliamentary Cttee. followed by Cabinet. I report on (1) Rhodesia in Security Council - things are going badly there since the 5 Afro-Asians, 2 Communists, plus 
Brazil (whose adherence the Afro-Asians have secured by promising not to pillory Portugal) and Paraguay, seem resolved to press a motion of a kind we should have to veto; inter alia it would prescribe for us whom we should, or should not negotiate with in the future. I have authorised Caradon to tell the Afro-Asians plainly that we shall veto if they persist, and this may do the trick. 2) Breakdown of negotiations over aid to South Yemen; this may well be a blessing in disguise, since the idea of any further aid to them is -deservedly - unpopular here - but we had to make an offer, as we had promised to do so last November. 3) Middle East - some revival of hope, since all concerned have agreed to let their U.N. representatives talk (separately) with Jarring in New York. Harold, quoting telegrams, ascribes this, in part, to my effort - and indeed I had taken great pains with Eban, King Hussein and the U.A.R. Ambassador here.

Friday May $17^{\text {th }}$

Usual meeting with P.M., Leader of House, Dick Crossman and Chief Whip, about next week's business - nothing special. Talk to Fred Mulley at F.O. about plans for the F.O./C.O. merger, which are getting into difficulties.

An odd visit from the Kuwait Ambassador, who wants me to agree to the principle that we should compensate them for devaluation. I tell him this is not on; he says it might be done through generous treatment of them over sale of arms to them; I say sales must be dealt with on their merits. I think he is fishing for information about the possibility of another devaluation, but I give him no grounds for thinking this is likely. ${ }^{98}$ 
$\underline{\text { Monday May } 20^{\text {th }}}$

Morning, discuss P.Q's... When Question Time comes it goes well, but is quiet, and a thin House.

Office meeting to discuss the Planning Section of the F.O. This is small and competent; I ask to have quarterly talks with the Planners, and suggest that they should consider the question of an affluent argumentative society - such as the West can keep in condition to resist Communism's Spartan attitude.

David Bruce, U.S. Amb. arrives with message from Rusk about Vietnam and my Moscow visit. We discuss this further in the afternoon with Sullivan and Davidson $^{99}$, who are over for the Paris talks. They expect these to be slow - perhaps dragging on with nothing settled till after the U.S. elections - but do NOT expect Hanoi to walk out. We agree that in Moscow I should point out that U.S. want a real (but not necessarily admitted) quid pro quo for complete cessation of bombing, in the form of proper observance of the Demilitarised Zone, and reduction of N. Vietnam's use of Laos as a supply route; to this end the Co-Chairmen should try to make the I[nternational] C[ontrol] C [omission $]^{100}$ a real body - which the Russians could do by giving the necessary instructions to the Poles. Hint that if Hanoi will not do this, US public opinion might more readily become hawk-ish than dove-ish. Further, U.S. military withdrawal would have to be matched by withdrawal of N. Vietnam forces from S. Vietnam. We also discuss possible settlement of main issue, but this clearly lies some way ahead.

Ronnie Mackintosh, formerly of DEA, now at Cabinet Office, comes to report how the officials of the Europe Committee discussed my paper on a possible British 
initiative. It will clearly be a difficult Ministerial meeting tomorrow, and we shall have to be flexible on the timing if we are to get the main idea accepted.

A long evening, studying - in addition to routine papers - the briefs for Moscow and for the Europe meeting.

$\underline{1969}$

$\underline{\text { Wednesday, January } 1^{\text {st }}}$

I get a C[ompanion of] $\mathrm{H}$ [onour] in the Honours List. Several kind messages, especially from the Office... Back to a large and difficult box. None of the difficult problems - Middle East, Nigeria ${ }^{101}$, Vietnam, Anthony Grey in China ${ }^{102}$, or Europe seem any nearer solution: though it may be that the recent Israeli attack on Beirut airport will act as a catalyst and make possible 'imposed' solution by the four Permanent Members.

Thursday, Jan. $2^{\text {nd }}$

To office: Fred Mulley talks to me about Barbara's proposals for T.U. law; he fears that we shall land ourselves in great difficulties without producing any useful result, and I am inclined to agree. Settle, in Fred's favour, a demarcation dispute between him and Alun Chalfont, concerning gas centrifuge; he says Alun may resign because he has not enough to do. I must get rid of one of my junior Ministers preferably Bill Whitlock ${ }^{103}$; but this will have to wait till Harold is less pre-occupied with the C'wealth Conf. ${ }^{104}$ Smirnovsky comes to see me with a message and outline 
plan for the Middle East. The message is harshly anti-Israel and I demur to this - tho' pointing out that we have warned Israel of the dangers of refusing to carry out the UN Resolution. The plan, however, is much more balanced and I will tell my own officials that it must be approached constructively.

[Later] to No. 10 to see Harold. Barbara is there and says that Woodcock applauds her policy. If he is prepared to say this publicly it greatly alters the position. Harold tells me he is still thinking of the possibility of an election in the Spring of 1970. We discuss C'wealth Conf. details. Then have to lunch. Back to office to talk to Hugh Caradon, who is still very rigid about the 'Fearless' proposals. ${ }^{105}$ Then a large Office meeting about the C'wealth Conf. After this Paul Wright, formerly at the UN and now Ambassador-Designate to Kinshasa comes to see me. He is very keen on this difficult post, and I think will do well. Then Gwyn Morgan ${ }^{106}$ from T[ranspor]t House; we sort out the tiresome business of Sam Silkin's ${ }^{107}$ candidature for the SecGen'ship of the Council of Europe, and he gives me good advice about tomorrow's meeting with the NEC.

\section{Fri. Jan. $2^{\text {nd }}$.}

Cabinet, morning and afternoon, chiefly concerned with Barbara's proposals for T.U. legislation. She has a good case but is too verbose and emphatic in presenting it. We do not reach a final decision but things are clearly going her way. Harold issues a warning that Ministers must not talk to T.Uists in a way that queers Barbara's pitch.

[Later] receive Overseas Cttee of NEC and we discuss Nigeria and Rhodesia: it goes well, though Walter Padley ${ }^{108}$ does his best to make trouble. After the meeting 
I ask Fred Mulley to give special attention to liaison between the F[oreign and] C[ommonwealth] O[ffice] \& Tpt. House. 


\section{Notes}

${ }^{1}$ I am grateful to the staff of Churchill College Archive Centre for their help with this project and to Julie Young and Matthew Yandell for typing up the original text from Michael Stewart's handwritten manuscript.

2 Tony Benn, Out of the Wilderness: diaries 1963-67 (Hutchinson, 1987) and Office without Power: diaries, 1968-72 (Hutchinson, 1988); Barbara Castle, The Castle Diaries 1964-70 (Weidenfeld and Nicolson, 1984); Richard Crossman, The Diaries of a Cabinet Minister, Volume One, Minister of Housing 1964-66 (Hamish Hamilton and Jonathan Cape, 1975), Volume Two, Lord President of the Council and Leader of the House of Commons 1966-68 (Hamish Hamilton and Jonathan Cape, 1976), and Volume Three, Secretary of State for Social Services 1968-1970 (Hamish Hamilton and Jonathan Cape, 1977).

${ }^{3}$ Denis Healey, The Time of My Life (Michael Joseph, London, 1989); Edward Pearce, Denis Healey (Little, Brown, London, 2002), see 1.

${ }^{4}$ Robert Pearce, ed., Patrick Gordon Walker: political diaries, 1932-71 (The Historians' Press, London, 1991), has entries for thirty days in 1965-69.

${ }^{5}$ Michael Stewart, Life and Labour (Sidgwick and Jackson, London, 1980), 208-55.

${ }^{6}$ Roy Jenkins, A Life at the Centre (Macmillan, Basingstoke, 1991), 234-5.

${ }^{7}$ Bryan Gould, Goodbye to all That (Macmillan, Basingstoke, 1995), 54; Henry

Kissinger, The White House Years (Weidenfeld and Nicolson, London, 1979), 92; Healey, Time of My Life, 297.

${ }^{8}$ Barbara Castle, Fighting all the Way (Weidenfeld and Nicolson, London, 1993), $382-3$.

${ }^{9}$ Nicholas Henderson, Mandarin (Weidenfeld and Nicolson, London,1994), 420. 
${ }^{10}$ Jack Ashley, Acts of Defiance (1992), 146 and 173-4; Nicholas Henderson, Inside the Private Office (Weidenfeld and Nicolson, London, 1987), chapter 8; Donald Maitland interview, Diplomatic Oral History Archive, Churchill College, Cambridge, 13.

${ }^{11}$ These are preserved in series STWT 8/1 at Churchill College Archive Centre, Cambridge. Stewart died in 1990.

${ }^{12}$ On 31 March US President Lyndon B. Johnson had made a televised speech withdrawing from the 1968 Presidential race, restricting the American bombing campaign against North Vietnam and offering Vietnam peace negotiations.

${ }^{13}$ A reference to earlier fears, in Parliament and the Press, that the Foreign Office was about to strike a deal with Argentina on the future of the Falkland Islands.

${ }^{14}$ Minister of State at the Foreign Office.

${ }^{15}$ Britain had been co-Chair, along with the USSR, of the 1954 Geneva conference, which had divided Vietnam between North and South. There was a real possibility that the conference would be reconvened to help resolve the Vietnam War and the British argued that this made it essential for them to maintain a balanced approach to the conflict. While generally sympathetic to American policy, Wilson had criticised the US bombing of targets near Hanoi in June 1966.

${ }^{16}$ Minister of Power; became Minister of Transport in the reshuffle soon afterwards.

${ }^{17}$ Castle was Minister of Transport, but shortly to become Secretary for Employment and Productivity. Benn was Minister of Technology.

${ }^{18}$ Stewart's wife.

${ }^{19}$ Chancellor of the Exchequer, widely seen at this point as Wilson's most likely successor.

${ }^{20}$ Secretary of Defence. 
${ }^{21}$ In particular there had been pressure in the Cabinet for some time to withdraw from the European Launcher Development Organisation (ELDO), which the Conservative government had helped set up in 1962. The Foreign Office was concerned over the effect that withdrawal would have on friendly members of the EEC.

${ }^{22}$ UN Resolution 242 of November 1967, based on a British draft, was now the basis of talks on a Middle East peace. It called on Israel to withdraw from territory conquered during the June 'Six Day' War, while the Arabs would guarantee future Israeli security.

${ }^{23}$ The line of the Oder-Neisse river had marked the German-Polish border since 1945, lying well to the West of the pre-Second World War border.

${ }^{24}$ The post of First Secretary had been created in 1964 for George Brown, Labour's deputy leader, when he became the first head of the Department of Economic Affairs, a ministry designed to break the hold of the Treasury over economic policy and boost growth. The Department was wound up in 1969.

${ }^{25}$ Minister of Overseas Development.

${ }^{26}$ The Suez Canal had been closed as a result of the Six Day War and the British, as a major trading power, were keen to see it reopen.

${ }^{27}$ Israeli foreign minister.

${ }^{28}$ King, the American civil rights campaigner, had been assassinated on 4 April.

${ }^{29}$ Labour MP for Woolwich East, had resigned as Navy Minister in 1966 due to defence cuts.

${ }^{30}$ Parliamentary Secretary at the Board of Trade.

${ }^{31}$ Home Secretary.

${ }^{32}$ Formerly Minister of Agriculture, had become Lord President of the Council and Leader of the House of Commons in the reshuffle. 
${ }^{33}$ Richard Crossman, formerly Leader of the House of Commons, had just become Secretary of State for Social Services.

${ }^{34}$ Rodgers was Parliamentary Under-Secretary at the Foreign Office. A military regime had seized power in Greece in June 1967. The regime was widely condemned, not least by the Labour left but British government policy was restrained by the fact that Greece was a fellow member of NATO.

${ }^{35}$ Brown had resigned as Foreign Secretary in March but remained a significant figure as deputy leader of the Labour Party.

${ }^{36}$ Ambassador to Paris.

${ }^{37}$ President Charles de Gaulle of France had vetoed British applications to join the European Economic Community in January 1963 and November 1967.

${ }^{38}$ Dutch foreign minister.

${ }^{39}$ Hammersmith Borough Council did indeed fall to the Conservatives in the May local elections, ending thirty-four years of Labour control, but Stewart held the Fulham constituency in the June 1970 general election.

${ }^{40}$ Paul Gore-Booth, Permanent Under-Secretary of the Foreign Office.

${ }^{41}$ Secretary of State for Commonwealth Affairs.

${ }^{42}$ Secretary of State for Scotland.

${ }^{43}$ President of Zambia. His country bordered on Rhodesia (later known as Zimbabwe), a British colony, which had declared independence unilaterally in November 1965 under a white supremacist regime and against which international sanctions had been introduced.

${ }^{44}$ Ambassador to Washington.

${ }^{45}$ Head of South-East Asia Department, Foreign Office.

${ }^{46}$ Soviet foreign minister. 
47 The project, later developed by Britain, Holland and Germany to enrich uranium using a gas centrifuge process.

${ }^{48}$ Chief Scientists in both countries.

${ }^{49}$ The members of the EEC other than France were all favourable to British entry to the EEC and were frequently referred to as 'the Five' or 'the Friendly Five'.

${ }^{50}$ President of the European Commission.

${ }^{51}$ Italian foreign minister.

${ }^{52}$ Established in 1955, the WEU was of little value as a security alliance because of the much greater significance of NATO; but it was a useful forum for discussion at this point because it included Britain and all six members of the EEC.

${ }^{53}$ German foreign minister.

${ }^{54}$ Stewart's Private Secretary at the Foreign Office.

${ }^{55}$ CENTO, a Middle Eastern version of NATO but with little military effectiveness, had originated in the partly-British inspired Baghdad Pact of 1955. The only Arab member, Iraq, had left in 1958, leaving it as a pro-Western group, tying together Turkey, Iran and Pakistan, alongside the British and Americans.

56 The Shah of Iran claimed certain islands in the Persian Gulf, including Bahrain. Their future had become more uncertain since the British decision in January 1968 to withdraw its forces from the Gulf where they had traditionally defended Bahrain and other sheikhdoms.

${ }^{57}$ Mulley was Minister of State at the Foreign Office and Allen a Deputy UnderSecretary.

${ }^{58}$ In order to bring an end to the apartheid regime, many African and Asian countries wished to introduce UN sanctions against trade with South Africa, but the country was one of Britain's largest export markets. Britain had agreed to restrict arms sales to 
South Africa (especially those that could be used for internal suppression) but, like the US, was opposed to a general boycott of trade.

${ }^{59}$ The Foreign Office and Commonwealth Office were formally merged on 17 October 1968 to create the Foreign and Commonwealth Office. Such a merger between the ministries responsible for overseas policy had been proposed since the 1940s and became more likely after the 1964 Plowden Report. The Commonwealth Office had itself been produced by a merger of the old Colonial Office and Commonwealth Relations Office in August 1966.

${ }^{60}$ Greenhill, a Deputy Under-Secretary since 1966 , had already been identified as Gore-Booth's likely successor earlier in the year by George Brown.

${ }^{61}$ Minister of State at the Commonwealth Office.

${ }^{62}$ Minister of State at the Foreign Office. A former journalist, he was heavily reliant on the patronage of the Prime Minister, who had originally appointed him as 'Minister for Disarmament' in the Foreign Office, later moving him to be the 'Minister for Europe', handling the failed 1967 bid to enter the EEC.

${ }^{63}$ French foreign minister.

${ }^{64}$ George Brown had chosen Roger Jackling to succeed Roberts as Ambassador to Bonn, an appointment that took effect in May 1968. O'Neill, a former Head of the British delegation to the European Communities and Deputy Under-Secretary, was so upset not to obtain the post that he resigned.

${ }^{65}$ A British-born senior official in the Israeli foreign ministry.

${ }^{66}$ Guatemala claimed the whole territory of British Honduras, a colony on the coast of Central America. In 1965 the two countries put the claim to American arbitration and President Johnson appointed Bethuel Webster as arbitrator. His report failed to settle 
the problem: when the colony became independent as Belize, in 1981, British troops remained due to the fear of Guatemalan invasion.

${ }^{67}$ The US and Soviet ambassadors in London. The treaty, designed to stop the nuclear arms race spreading into space, banned nuclear weapons from the moon and other celestial bodies.

${ }^{68}$ That is Deputy Under-Secretary of State.

${ }^{69}$ The Greek-Cypriot Archbishop Makarios III had become President of Cyprus when it achieved independence from Britain in 1960, but he was distrusted by the minority Turkish-Cypriot community. There was violence between the two communities in 1964 and 1967, with the danger that Greece and Turkey might intervene. Britain was anxious to resolve the problem and hoped to smooth the way to a settlement by offering up the territory of the two British sovereign military bases that had been retained on the island after independence.

${ }^{70}$ Eugene McCarthy was an anti-war candidate in the US Presidential election campaign.

${ }^{71}$ The German neo-Nazi 'National Democratic Party'.

${ }^{72}$ Former Ambassador to Syria.

${ }^{73}$ Secretary to the Cabinet.

${ }^{74}$ Conservative foreign affairs spokesman; a former Foreign Secretary and Prime Minister.

${ }^{75}$ For stronger international sanctions against Rhodesia following the outrage caused by the execution of three Black opponents of the regime in March. The British draft resolution called for an end to all trade with Rhodesia, exchange control measures and denial of entry to those carrying Rhodesian passports. The United Nations introduced 
comprehensive mandatory sanctions against Rhodesia in May, but they were widely ignored.

${ }^{76}$ A reference to the British government's opposition to sanctions against and Portugal (at that time the colonial power in Mozambique, bordering Rhodesia) and South Africa, the principal countries involved in breaking the UN sanctions policy against Rhodesia.

${ }^{77}$ Lord Chancellor.

${ }^{78}$ President of the Board of Trade.

${ }^{79}$ Secretary of State for Wales.

${ }^{80}$ On 20 April the Conservative MP, Enoch Powell, had made a speech in Birmingham criticising the government's Race Relations Bill (then due to receive its second reading in the Commons), attacking coloured immigration into Britain and saying that, 'Like the Roman, I seem to see the River Tiber foaming with much blood.' He was sacked from the Shadow Cabinet the following day.

${ }^{81}$ Britain was a founder member of EFTA in 1960, alongside Sweden, Norway, Denmark, Austria, Switzerland and Portugal. It had partly been designed to strengthen Britain's hand in negotiations with the EEC but was far weaker - both economically and politically - than the latter organisation.

${ }^{82}$ In November 1967 British troops had left the former colony of Aden and its neighbouring protectorates, handing power to a Marxist liberation movement, the national Liberation Front, which established the People's Republic of South Yemen. As part of a last-minute independence deal the British government had promised to discuss an aid package with the new government.

${ }^{83}$ General Secretary of the Amalgamated Union of Engineering Workers. 
${ }^{84}$ Sachsenhausen was a Nazi concentration camp. A number of former prisoners had complained that they had been denied compensation by the Foreign Office available under an Anglo-German agreement and, following earlier complaints in the Commons, the Parliamentary Commissioner (known as the Ombudsman) agreed with them. It was one of the earliest judgements by the Ombudsman.

${ }^{85}$ Former Ambassador to Bonn.

${ }^{86}$ Bottomley was a former Secretary of State for Commonwealth Relations (1964-6) and Minister for Overseas Development (1966-7).

${ }^{87}$ Briefly Permanent Under-Secretary of State at the Commonwealth Office.

${ }^{88}$ Conservative MP for Windsor, a former diplomat and frequent Conservative spokesman on foreign affairs.

${ }^{89}$ Jack Ashley, Labour MP for Stoke-on-Trent and Stewart's PPS, became totally deaf as the result of an operation carried out in December 1967. He remained an MP and even returned to government as PPS to Barbara Castle at Social Services in 1974. ${ }^{90}$ There had been considerable media coverage of Gore-Booth's trip to the Reichenbach Falls in Switzerland where the fictional encounter between Sherlock Holmes and Moriarty took place. Gore-Booth was President of the Sherlock Holmes Society and had been accompanied by Adrian Conan Doyle, the son of Holmes' creator, Sir Arthur.

${ }^{91}$ In November 1967 Jarring, a Swedish diplomat who had served as Ambassador to the UN, was appointed by the UN Secretary General, Sithu U Thant, to be his Special Representative in the Middle East, exploring the possibilities of a peace settlement on the basis Resolution 242 .

${ }^{92}$ Spain had ceded Gibraltar to Britain in the Treaty of Utrecht of 1713 but had secured a vote at the UN in 1963 to have its colonial status terminated. The Spanish 
government, then under the dictatorship of General Francisco Franco, had begun to restrict traffic across the land border in 1964 but the British maintained access by sea and (with some trouble) by air. A referendum in September 1967 had seen only 44 Gibraltarians out of 12,000 vote for a return to Spanish rule.

${ }^{93}$ Gerald Brooke had been imprisoned by the Soviet authorities in 1965 for carrying anti-Soviet propaganda materials. In June 1969 the British cabinet agreed to exchange him for Peter and Helen Kroger, two Soviet spies who had been imprisoned in 1961. George Blake was another Soviet spy who was imprisoned in 1961 but he had escaped from Wormwood Scrubs to the USSR in 1966.

${ }^{94}$ French finance minister.

${ }^{95}$ In fact Couve de Murville did become French prime minister in July.

${ }^{96}$ As well as launching this Press campaign, Cecil King, the Chairman of the International Publishing Corporation (which owned The Sun) had been trying to organise a coup against Wilson, intending to replace him with some kind of coalition government, a scheme in which he had tried to involve Lord Mountbatten.

${ }^{97}$ Smith was Rhodesian prime minister and the Beira patrol was a Royal Navy operation to enforce economic sanctions against Rhodesia by preventing oil tankers from reaching the port of Beira in Portuguese-controlled Mozambique (which provided the most convenient route to land-locked Rhodesia).

${ }^{98}$ Despite a substantial devaluation of the Pound Sterling in November 1967, from $\$ 2.80$ to $\$ 2.40$, there was continuing speculation (especially in March 1968) that a further devaluation would be necessary. Holders of Sterling (still a major trading currency at that time) were concerned at the sale of their losses in such circumstances. The uncertainty did not finally ease until early 1969. 
${ }^{99}$ William Sullivan, US Ambassador to Laos, and Daniel Davidson, Special Assistant to the Ambassador-at-Large.

100 The ICC, which included members from Canada, India and Poland, had been set up in 1954 to monitor the Geneva Agreements of that year on Indochina (which, among other steps, had divided Vietnam between North and South).

${ }^{101}$ Civil war had broken out in Nigeria in July 1967 and, from the Spring of 1968, the British government was criticised from many quarters for supporting the Federal Military Government in its attempts to end the secession of Eastern Nigeria (which had declared independence as 'Biafra'). The war dragged on until early 1970. ${ }^{102}$ Grey was a journalist who had been imprisoned in his home by the Communist authorities since July 1967.

${ }^{103}$ Parliamentary Under-Secretary at the Foreign and Commonwealth Office.

${ }^{104}$ A Commonwealth Conference was due to meet in London on 7-15 January.

${ }^{105}$ Wilson had met the Rhodesian premier Ian Smith on board H.M.S. Fearless at Gibraltar in October 1968, to try to reach a settlement of the Rhodesian problem. The proposed terms were much criticised in Britain but, in the event, rejected by the Rhodesian cabinet.

${ }^{106}$ Assistant General-Secretary of the Labour Party.

${ }^{107}$ Labour MP, brother of the Chief Whip, John Silkin.

${ }^{108}$ Labour MP, Chair of the Labour Party's Overseas Committee and a former (19647) Minister of State at the Foreign Office. 